Article

\title{
Dellagiustaite: A Novel Natural Spinel Containing $\mathrm{V}^{2+}$
}

\author{
Fernando Cámara ${ }^{1, *(D)}$, Luca Bindi ${ }^{2} \mathbb{D}$, Adriana Pagano ${ }^{3}$, Renato Pagano ${ }^{3}$, Sarah E. M. Gain ${ }^{4,5}$ (D) \\ and William L. Griffin ${ }^{4}$ (D)
}

1 Dipartimento di Scienze della Terra “A. Desio”, Università degli Studi di Milano, Via Luigi Mangiagalli 34, 20133 Milano, Italy

2 Dipartimento di Scienze della Terra, Università degli Studi di Firenze, Via G. La Pira 4, I-50121 Firenze, Italy; luca.bindi@unifi.it

3 Casella Postale 37, Cinisello, 20092 Milano, Italy; adrianapagano@virgilio.it (A.P.);

renato.pagano@gmail.com (R.P.)

4 Australian Research Council Centre of Excellence for Core to Crust Fluid Systems (CCFS)/GEMOC,

Earth and Planetary Sciences, Macquarie University, NSW 2109, Australia;

sarah.gain@mq.edu.au (S.E.M.G.); bill.griffin@mq.edu.au (W.L.G.)

5 Centre for Microscopy, Characterisation and Analysis, The University of Western Australia, Crawley, WA 6009, Australia

* Correspondence: fernando.camara@unimi.it; Tel.: +39-02-503-15600

Received: 28 November 2018; Accepted: 19 December 2018; Published: 21 December 2018

\begin{abstract}
Dellagiustaite, ideally $\mathrm{Al}_{2} \mathrm{~V}^{2+} \mathrm{O}_{4}$, is a new spinel-group mineral from Sierra de Comechingones, San Luis, Argentina, where it is found associated with hibonite (containing tubular inclusions, 5-100 $\mu \mathrm{m}$, of metallic vanadium), grossite, and two other unknown phases with ideal stoichiometry of $\mathrm{Ca}_{2} \mathrm{Al}_{3} \mathrm{O}_{6} \mathrm{~F}$ and $\mathrm{Ca}_{2} \mathrm{Al}_{2} \mathrm{SiO}_{7}$. A very similar rock containing dellagiustaite has been found at $\mathrm{Mt}$ Carmel (northern Israel), where super-reduced mineral assemblages have crystallized from high- $T$ melts trapped in corundum aggregates (micro-xenoliths) within picritic-tholeiitic lavas ejected from Cretaceous volcanoes. In the holotype, euhedral grains of dellagiustaite are found as inclusions in grossite. The empirical average chemical formula of dellagiustaite is $\left(\mathrm{Al}_{1.09} \mathrm{~V}_{0.91}^{2+} \mathrm{V}_{0.87}^{3+} \mathrm{Mg}_{0.08} \mathrm{Ti}_{0.04}^{3+} \mathrm{Mn}_{0.01}\right)_{\Sigma 3} \mathrm{O}_{4}$, but it may show limited replacement of $\mathrm{V}^{2+}$ by $\mathrm{Mg}$ and of $\mathrm{V}^{3+}$ by $\mathrm{Al}$. As $\mathrm{Al}$ is the dominant trivalent cation, the ideal formula is $\mathrm{Al}_{2} \mathrm{~V}^{2+} \mathrm{O}_{4}$ according to the current IMA rules. Dellagiustaite shows the usual space group of spinel-group minerals $\left(F d \overline{3} m, R_{1}=1.46 \%\right)$ with $a=8.1950(1) \AA$. The observed mean bond lengths $\left.<T-\mathrm{O}\right\rangle=1.782(2) \AA$ and $\langle M-\mathrm{O}\rangle=2.0445(9) \AA$, the observed site scattering ( $T=13.3 \mathrm{eps}, M=22.5 \mathrm{eps})$, and the chemical composition show that dellagiustaite is an inverse spinel: $\mathrm{T}$ tetrahedra are occupied by $\mathrm{Al}^{3+}$, whereas $\mathrm{M}$ octahedra are occupied by $\mathrm{V}^{2+}$ and $\mathrm{V}^{3+}$, leading to the site assignment as ${ }^{T} \mathrm{Al}^{\mathrm{M}}\left(\mathrm{V}_{0.91}^{2+} \mathrm{V}_{0.88}^{3+} \mathrm{Al}_{0.09}^{3+}\right.$ $\left.\mathrm{Mg}_{0.08} \mathrm{Ti}_{0.03}^{3+} \mathrm{Mn}_{0.01}\right) \mathrm{O}_{4}$.
\end{abstract}

Keywords: dellagiustaite; spinel supergroup; oxyspinel subgroup; new mineral species; crystal structure; Sierra de Comechingones; Argentina; Mt Carmel; Israel

\section{Introduction}

A new classification has been introduced recently for the spinel supergroup [1], based on chemical information alone. It has two criteria: the cation to anion ratio (3:4) represented by the general formula $\mathrm{AB}_{2} \mathrm{X}_{4}$, the dominant charge and the dominant constituent (A or B). From a structural point of view, minerals of the spinel supergroup show a structure consisting on a heteropolyhedral framework of 4-fold and 6-fold polyhedra ( $T$-sites and $M$-sites, respectively), the latter sharing half of the edges, 
which host A and B cations, whereas anions form a cubic close-packing and are four-fold coordinated. The new classification distributes 52 mineral species into three groups based on anion type $(\mathrm{O}, \mathrm{S}$ or Se). Those mineral species having the above organization and oxygen as the packing anion are classified into the oxyspinel group, internally subdivided in terms of dominant charge and dominant constituent: oxyspinel species with $\mathrm{A}^{2+} \mathrm{B}_{2}^{3+} \mathrm{O}_{4}$ formula belong to the spinel subgroup. Spinel structures frequently show cation order/disorder among the $T$ - and $M$-sites, leading to a structural formula ${ }^{T}\left(\mathrm{~A}_{1-\mathrm{i}} \mathrm{B}_{\mathrm{i}}\right)^{M}\left(\mathrm{~A}_{\mathrm{i}} \mathrm{B}_{2-\mathrm{i}}\right) \mathrm{X}_{4}$, with two extreme distributions corresponding to $i=0$ (normal spinels) and $i=1$ (inverse spinels). The new classification scheme, being based on chemical data only, does not take into account this feature. However, it is not a negligible one, as the value of $i$ depends on equilibration temperature, oxygen fugacity, crystal growth kinetics, covalence effects and stabilization energies at the $M$-sites ([2] and references therein). Cation order-disorder phenomena in spinel-group minerals represent a non-convergent ordering transformation [3,4] and knowledge of the equilibrium energetics allows for the estimation of the equilibration temperature, from which geothermometric determinations can be obtained. The inversion parameter is also important because physical properties of spinel, such as magnetism, electrical conductivity, bulk modulus, thermal expansion, and compressibility, are largely affected by the order-disorder cation distribution [5]. Among the accepted V-bearing mineral species belonging to the spinel subgroup, three dominant compositions are known: coulsonite $\left(\mathrm{Fe}^{2+} \mathrm{V}_{2}^{3+} \mathrm{O}_{4}\right)$ magnesiocoulsonite $\left(\mathrm{Mg}^{2+} \mathrm{V}_{2}^{3+} \mathrm{O}_{4}\right)$ and vuorelainenite $\left(\mathrm{Mn}^{2+} \mathrm{V}_{2}^{3+} \mathrm{O}_{4}\right)$, all having $\mathrm{V}^{3+}$ as the dominant $\mathrm{B}$ constituent, while $\mathrm{A}$ is a divalent element. Based on the X-ray absorption work in [6] and the optical studies in [7], the coordination of $\mathrm{V}^{3+}$ in oxides and silicates is likely to be octahedral and therefore we expect $i=0$ in $\mathrm{V}^{3+}$-bearing spinels. However, the scenario can change if we consider different oxidation states for vanadium. Remarkably, vanadium oxidation state in spinels has been considered as an oxybarometer [8].

Dellagiustaite, $\mathrm{V}^{2+} \mathrm{Al}_{2} \mathrm{O}_{4}$, is a new mineral of the spinel supergroup. Its peculiarity resides in the fact that vanadium is the dominant A constituent, i.e. it is in the divalent state. Dellagiustaite therefore belongs to the oxyspinel group and the spinel subgroup. The mineral was found in rock samples coming from Sierra de Comechingones, San Luis, Argentina. The sample was provided by the mineral dealer Jorge Dascal (Buenos Aires, Argentina), who reported that the material was collected at Sierra de Comechingones, San Luis, Argentina. Unfortunately, no more details on the locality were made available.

Recently, dellagiustaite has also been found in late-stage pyroclastic ejecta of small Cretaceous basaltic volcanoes exposed on Mt Carmel (Israel); aggregates of hopper-formed corundum crystals (Carmel Sapphire ${ }^{\mathrm{TM}}$ ) are common in the tuffs of these volcanoes and in associated alluvial deposits, mainly in the Kishon River [9-12]. Later stage ejecta show the crystallization sequence: corundum + $\mathrm{Liq} \rightarrow$ (low-REE) hibonite $\rightarrow$ grossite + spinel \pm krotite $\rightarrow \mathrm{Ca}_{2} \mathrm{Al}_{3} \mathrm{O}_{6} \mathrm{~F}+$ fluorite. Spinel grains are $\mathrm{V}$-rich but classifiable as spinel sensu lato. However, a new retrieval contained high-V spinel grains whose compositions fit with dellagiustaite.

Dellagiustaite is named to honor Prof. Antonio Della Giusta (University of Padova, Italy, born 1941), an expert on the crystal chemistry and cation order-disorder phenomena in spinel group minerals. The new mineral and mineral name have been approved by the Commission on New Minerals, Nomenclature and Classification, International Mineralogical Association (IMA 2017-101). The holotype material (the refined crystal and a rock chip) is deposited in the mineral collections of the Museo delle Collezioni di Mineralogia, Gemmologia, Petrologia e Giacimentologia, Dipartimento di Scienze della Terra "A. Desio", Università di Milano, under the catalogue number MCMGPG-H2017-001, and in the mineral collection of A. and R. Pagano with a catalogue number 12794C.

\section{Occurrence and Paragenesis}

Sierra de Comechingones is a $100 \mathrm{~km}$ long formation at the southern sector of the Sierra Grande de Cordoba. It is composed of Neoproterozoic metamorphic rocks, mainly high grade migmatites, as well as Paleozoic granitoids. The Comechingones Metamorphic Complex, located between the Achala and Alpa Corral batholiths, encompasses cordierite-bearing diatexites and stromatic migmatites 
(Yacanto Group), with intercalations of mafic and ultramafic rocks (San Miguel Group), and garnet gneisses, marbles and kinzigites at granulite facies $[13,14]$. However, the metamorphic grade is not high enough for the formation of the peculiar mineral assemblage in which dellagiustaite is found. In fact, dellagiustaite is associated with hibonite $\left(\mathrm{CaAl}_{12} \mathrm{O}_{19}\right)$ and grossite $\left(\mathrm{CaAl}_{4} \mathrm{O}_{7}\right)$, which constitute the modal composition of the rock. Hibonite crystals are remarkable, and it is common to find cm-size purple euhedral phenocrysts (Figure 1).

Grossite occurs as interstitial light violet crystals up to a few millimeters across. Other phases present are gehlenite, aluminum-rich perovskite and a new calcium aluminate with ideal formula $\left(\mathrm{Ca}_{2} \mathrm{Al}_{3} \mathrm{FO}_{6}\right)$ corresponding to the synthetic phase calfidine $[15,16]$. Hibonite and grossite crystals frequently have tubular inclusions of a V-rich phase that is isostructural with a non-stoichiometric vanadium oxide with formula approximately of $\mathrm{V}_{2} \mathrm{O}$. These inclusions are related to pores running in the same direction and containing hexagonal plates of medium-crystalline graphite, which will be described in future publications. Dellagiustaite occurs in fractured hibonite and grossite crystals (Figure 2a,b and Figure 3). Tubular inclusions (Figure 4) resemble sulfide tubular inclusions within Al-augite pyroxenite xenoliths in undersaturated continental basalts. These inclusions could have formed due to immiscibility of sulfide melts, which nucleated on crystal surfaces ([17] and references therein).

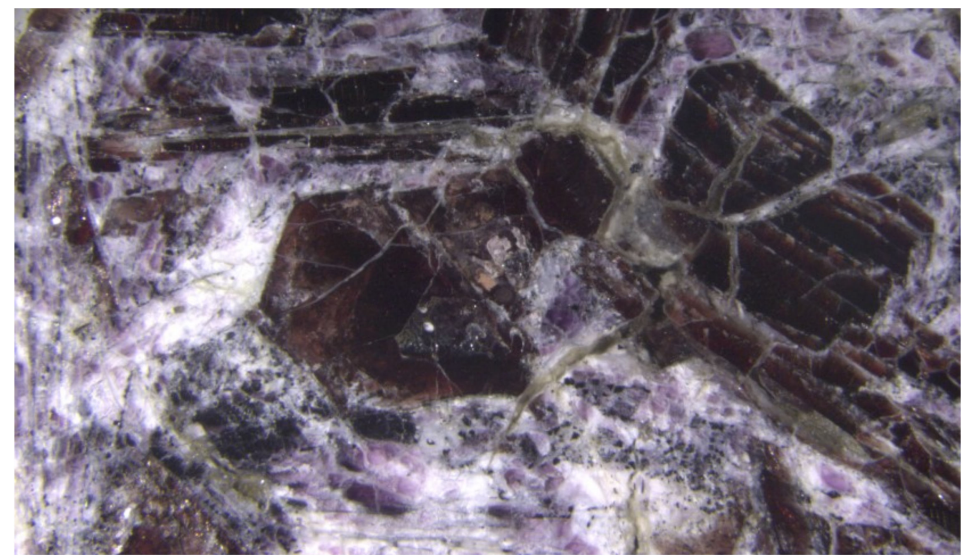

Figure 1. Section of the rock sample showing the hibonite phenocrysts (deep purple) in a matrix of grossite (violet) as well as other fluorine-bearing calcium aluminates and dellagiustaite. Field of view (FOV), $1.64 \mathrm{~cm}$.

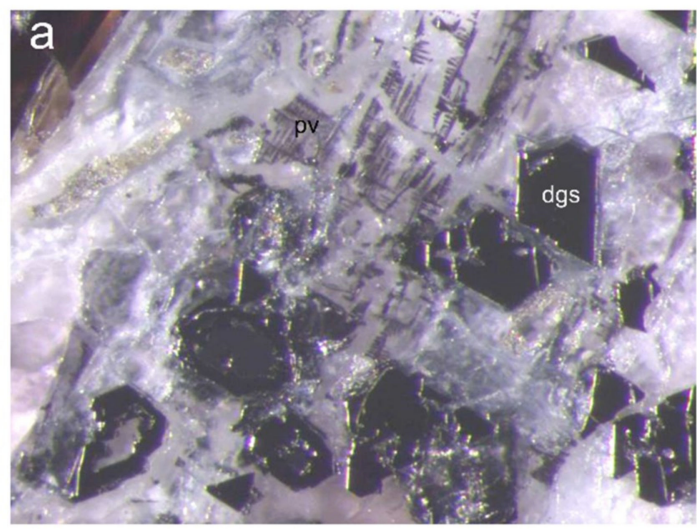

(a)

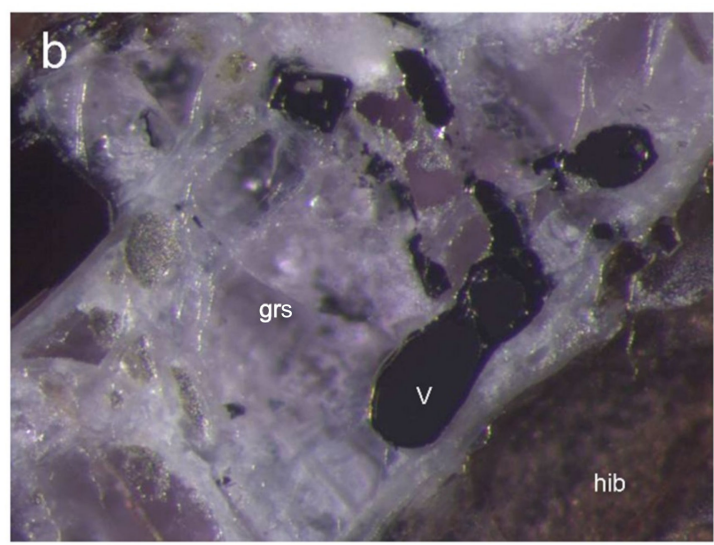

(b)

Figure 2. The type specimen with dellagiustaite: (a) euhedral crystals (dgs) are embedded in grossite containing also skeletal crystals of high-Al perovskite (pv); FOV $1.72 \mathrm{~mm}$; and (b) metallic vanadium (V) rimmed by dellagiustaite in grossite (grs) light violet matrix. Lower right angle is a portion of hibonite (hib) phenocryst. FOV, $1.72 \mathrm{~mm}$. 


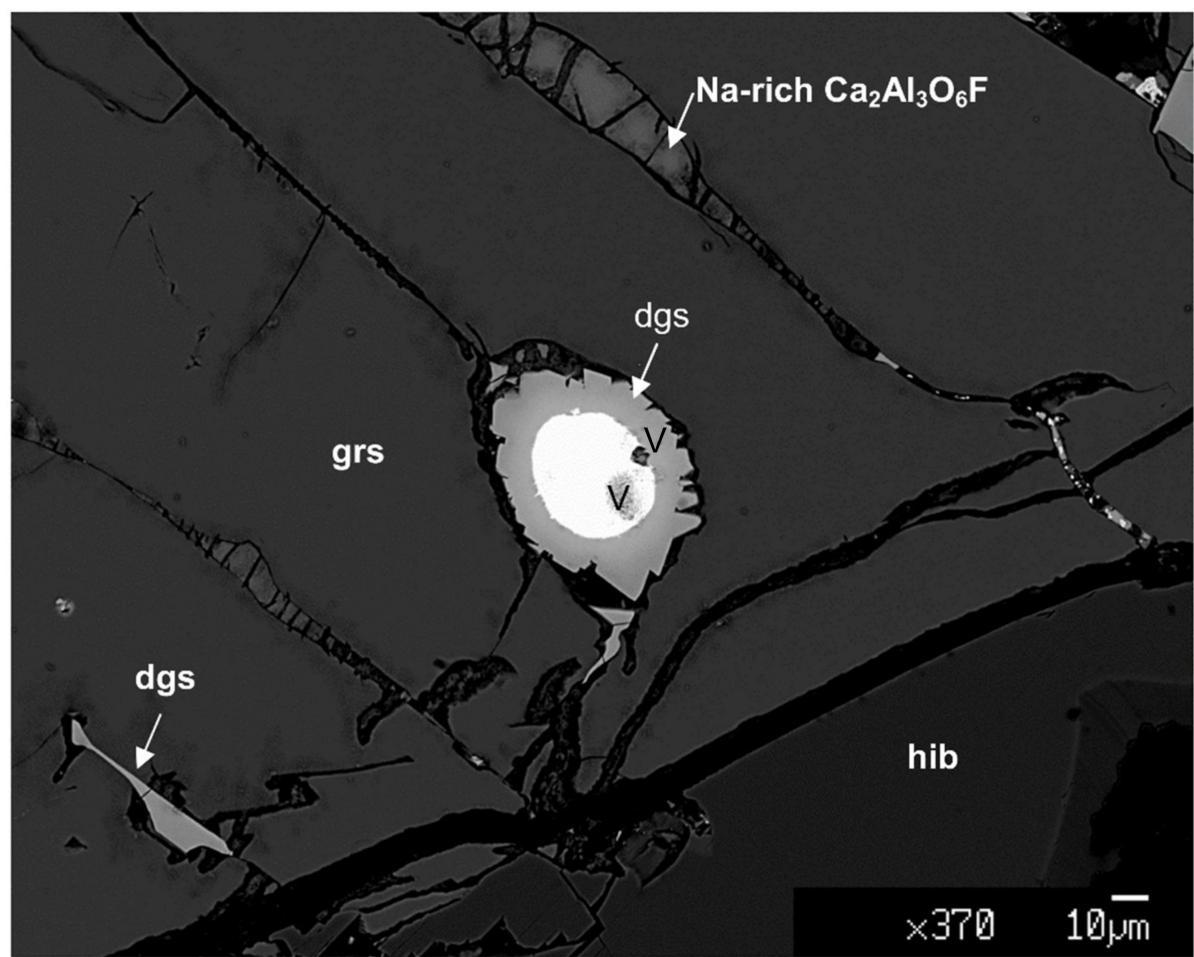

Figure 3. Backscattered Secondary Electrons Scanning Electron Microscopy (BSE-SEM) image of dellagiustaite (dgs) in the type specimen, rimming metallic $\mathrm{V}(\mathrm{V})$ included in grossite (grs). Lower darker right angle is hibonite (hib). Grossite shows veins of Na-rich $\mathrm{Ca}_{2} \mathrm{Al}_{3} \mathrm{FO}_{6}$.

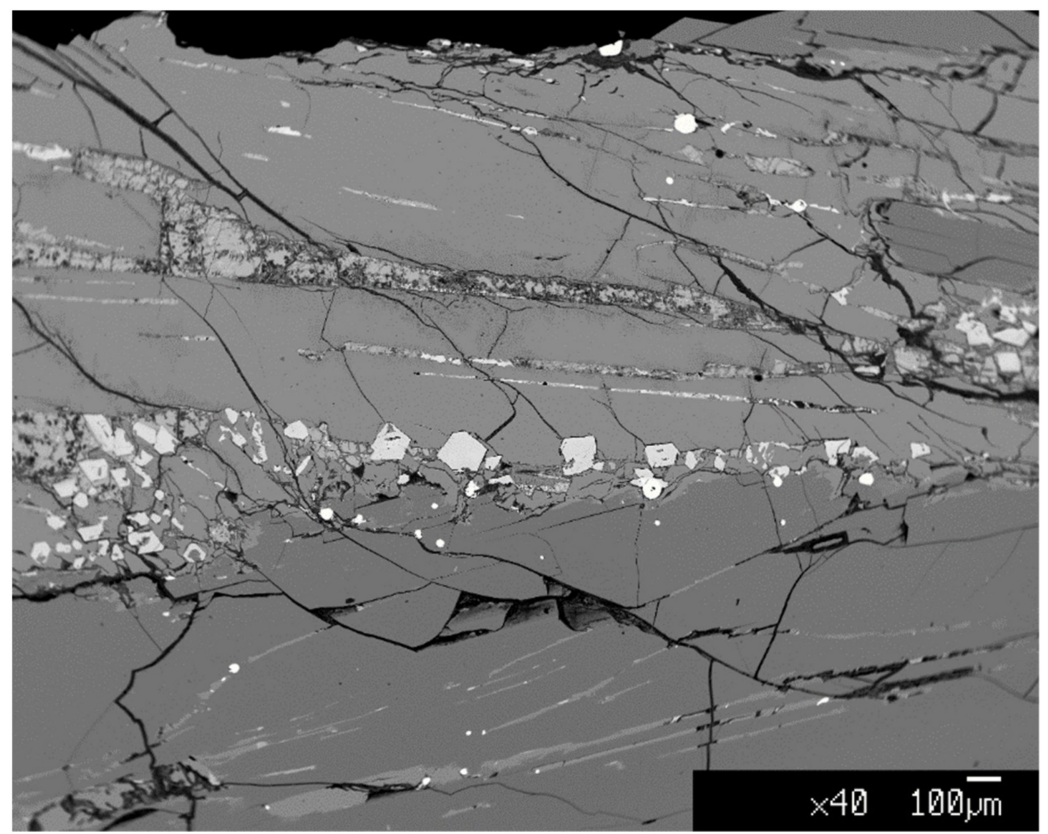

Figure 4. SEM-BSE image of dellagiustaite (bright idiomorphic crystals) in the type specimen and associated minerals (metallic V small bright spots and long darker trails related to tubular inclusions plunging deeper into the host, grossite lighter grey in upper half of the image, hibonite darker grey in lower part of the image). Dellagiustaite is associated with a sodium-rich $\mathrm{Ca}_{2} \mathrm{Al}_{3} \mathrm{O}_{6} \mathrm{~F}$ phase under study.

At Mt Carmel, dellagiustaite is associated with V-rich hibonite, grossite, krotite, $\mathrm{Ca}_{2} \mathrm{Al}_{3} \mathrm{O}_{6} \mathrm{~F}$ and fluorite, as well as an unidentified phase with stoichiometry close to a (K,V,Mg,Na)-rich Ca-depleted hibonite. The remarkable similarity of the assemblages from the two localities is also confirmed by 
the presence of metallic $\mathrm{V}$ and $\mathrm{V}$ alloys as spherules, rods and dense branching structures in hibonite and grossite.

Figure 5 reports the textural relations between the associated minerals at Mt Carmel. The rocks of Mt Carmel are also notable due to the significant amount of a V-Al alloy. This is the first reported in situ terrestrial Al-alloy, which probably is representative of the most reducing conditions yet documented on Earth.
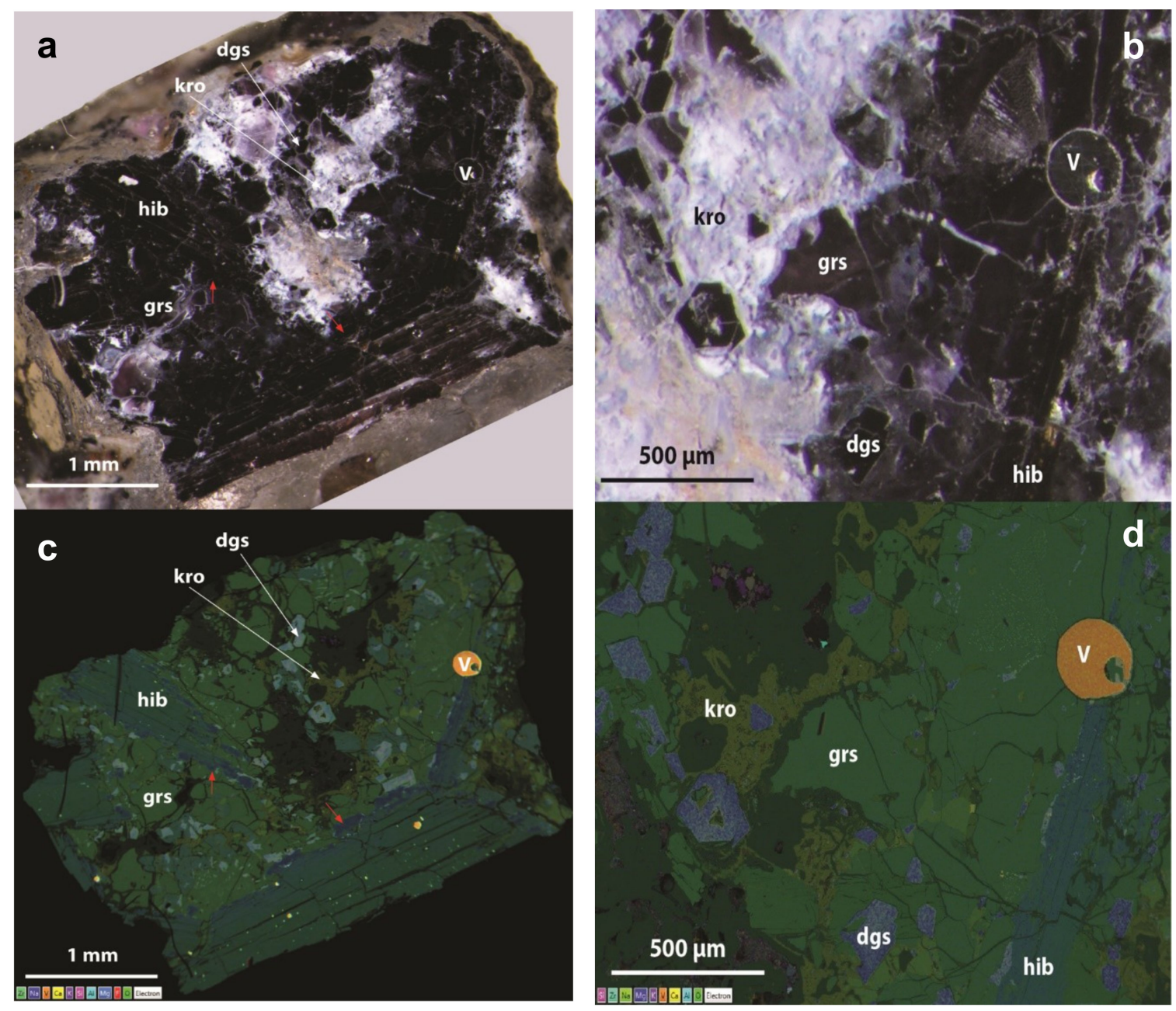

Figure 5. Optical image $(\mathbf{a}, \mathbf{b})$ and X-ray map image $(\mathbf{c}, \mathbf{d})$ of sample from Mt Carmel showing millimeter-size hibonite (hib) flat crystals embedded in a matrix of grossite (grs) and associated minerals (dellagiustaite, dgs: krotite, kro; V-Cr alloy, V). Smaller spinel grains are richer in the dellagiustaite molecule. Hibonite grains are richer in $\mathrm{K}, \mathrm{Na}, \mathrm{Mg}$ and $\mathrm{V}$, and depleted in $\mathrm{Ca}$ in the rims (zone marked with red arrow). (b,d): Enlarged view of the central-right part of the sample reported in Figure 5a,c, showing optical image (b) and X-ray map (d).

\section{Mineral Description and Physical Properties}

Dellagiustaite exhibits idiomorphic morphology (Figure 2a) with frequent $\{111\}$ forms; the crystals (up to $200 \mu \mathrm{m}$ ) are euhedral and/or subhedral and commonly overgrow tubular inclusions of a non-stoichiometric vanadium oxide.

Dellagiustaite crystals are black, opaque, show metallic luster and black streak, and are not fluorescent. Mohs hardness is ca 6.5-7, analogous to spinel. Tenacity is brittle and cleavage is not observed. Parting is irregular and conchoidal and fracture is uneven and splintery. Density could not be determined due to the frequent presence of vanadium inclusions in the crystals. Calculated density is $4.6 \mathrm{~g} \cdot \mathrm{cm}^{-3}$ (from ideal formula and unit-cell parameters from X-ray single-crystal data). 
In reflected light, the mineral is light grey and isotropic. In the holotype, no evidence of growth zonation is observed. Reflectance measurements were performed in air using an MPM-200 Zeiss microphotometer equipped with an MSP-20 system processor on a Zeiss Axioplan ore microscope. Filament temperature was approximately $3350 \mathrm{~K}$. An interference filter was adjusted, in turn, to select four wavelengths for measurement $(471.1,548.3,586.6$, and $652.3 \mathrm{~nm})$. Readings were taken for specimen and standard $(\mathrm{SiC})$ maintained under the same focus conditions. The diameter of the circular measured area was $0.07 \mathrm{~mm}$. Measurements of reflectance (in \%) are $14.1(471.1 \mathrm{~nm}), 13.8(548.3 \mathrm{~nm})$, $13.6(586.6 \mathrm{~nm})$, and $13.7(652.3 \mathrm{~nm})$.

\section{Chemical Data}

The chemical composition of dellagiustaite was determined using a JEOL 8200 Super Probe electron microprobe analyzer (EMPA) operating in X-ray wavelength-dispersive mode (WDS-EMPA) at the Department of Earth Sciences, University of Milan, Milan, Italy. Operating conditions included an accelerating voltage of $15 \mathrm{kV}$, a beam current of $5 \mathrm{nA}$, and a beam diameter of $1 \mu \mathrm{m}$, peak counting-time $30 \mathrm{~s}$ and $10 \mathrm{~s}$ in both peak sides background. Corrections of the raw data were made with the $\Phi \varrho Z$ procedures [18]. Spectral lines, analyzing crystals and standards used were: F K $\alpha$ (LDE1, hornblende

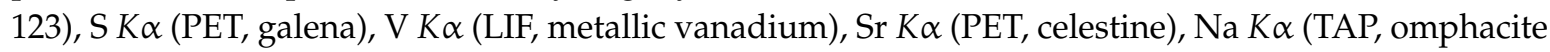

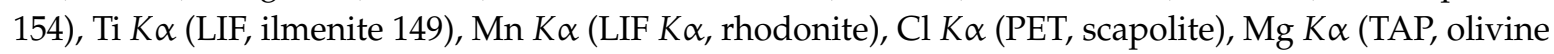

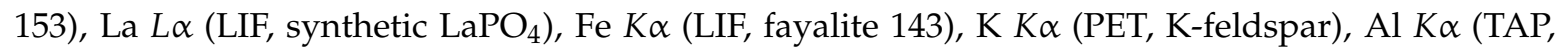

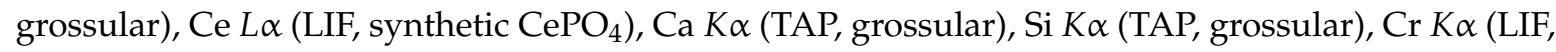
metallic $\mathrm{Cr}$ ), and $\mathrm{Ba} L \alpha$ (LIF, sanbornite). Overlap corrections of $\mathrm{V}$ on $\mathrm{Ti}$ and $\mathrm{Cr}$ on $\mathrm{V}$ were applied. Detection limits (in ppm) were F 599, S 259, V 299, Sr 350, Na 240, Ti 291, Mn 331, Cl 119, Mg 146, La 598, Fe 292, K 103, Al 180, Ce 588, Ca 147, Si 143, Cr 325, and Ba 321. The analytical results for dellagiustaite (mean results of eight spot analyses) are given in Table 1. Elements sought but not detected in dellagiustaite were $\mathrm{Si}, \mathrm{Fe}$ and $\mathrm{Cr}$. $\mathrm{VO} / \mathrm{V}_{2} \mathrm{O}_{3}$ ratio was calculated to obtain 3 atoms per formula unit (apfu). Ti was considered to be all as $\mathrm{Ti}^{3+}$ because the presence of $\mathrm{V}^{2+}$ implies that all the Ti must be trivalent at reduced conditions.

Table 1. Chemical analytical data (in wt.\%) for dellagiustaite.

\begin{tabular}{cccc}
\hline Constituent & Mean & Range & Probe Standard \\
\hline $\mathrm{MnO}$ & 0.20 & $0.14-0.31$ & Rhodonite \\
$\mathrm{MgO}$ & 1.82 & $1.17-2.24$ & olivine \\
$\mathrm{VO} \S$ & 32.38 & $29.73-33.15$ & \\
$\mathrm{~V}_{2} \mathrm{O}_{3}$ & 34.83 & $33.14-40.67$ & V metal \\
$\mathrm{Al}_{2} \mathrm{O}_{3}$ & 29.55 & $24.47-31.18$ & Grossular \\
$\mathrm{Ti}_{2} \mathrm{O}_{3}$ & 1.66 & $1.18-2.32$ & Ilmenite \\
\hline Total & 100.44 & \\
\hline & $\S$ calculated by stoichiometry.
\end{tabular}

Associated minerals were also analyzed and the results of representative analyses are reported in Table 2.

Samples from Mt Carmel were analyzed at the CCFS/GEMOC, Earth and Planetary Sciences, Macquarie University, Sydney, Australia with a Zeiss EVO MA15 scanning electron microscope operating in X-ray energy-dispersive mode (EDS) using an accelerating voltage of $15 \mathrm{keV}$ and a beam current of $1 \mathrm{nA}$. The SEM-EDS employs a standardless analysis technique, with peak positions recalibrated when necessary by analysis of a copper grid. The results are closely comparable to WDS-EMPA analysis for major elements and for minor elements at levels $>1 \mathrm{wt} . \%$ (cf. [12]). The analytical results for dellagiustaite in Mt Carmel are given in Table 3.

$$
\mathrm{V}_{0.91}^{2+} \mathrm{V}_{0.88}^{3+} \mathrm{Mg}_{0.08} \mathrm{Ti}_{0.03}^{3+} \mathrm{Mn}_{0.01}
$$

The empirical formula of dellagiustaite from the type locality, based on $4 \mathrm{O} a p f u$, is $\left(\mathrm{Al}_{1.09} \mathrm{~V}_{0.91}^{2+} \mathrm{V}_{0.88}^{3+} \mathrm{Mg}_{0.08} \mathrm{Ti}_{0.03}^{3+} \mathrm{Mn}_{0.01}\right)_{\Sigma 3} \mathrm{O}_{4}$. Based on the new classification of the spinel supergroup [1], 
dellagiustaite therefore belongs to the oxyspinel group $\left(\mathrm{AB}_{2} \mathrm{O}_{4}\right)$. According to the dominant valence and then the dominant $B$ constituent, dellagiustaite belongs to the spinel subgroup 2-3 $\left(\mathrm{A}^{2+} \mathrm{B}_{2}^{3+} \mathrm{O}_{4}\right)$ because the $\mathrm{B}$ constituents $\left(\mathrm{V}^{3+}+\mathrm{Al}\right)$ amount to $1.96 \mathrm{apfu}$. The mineral species is identified by the dominant A-cation, in this case $\mathrm{V}^{2+}(0.91 \mathrm{apfu})$. Because $\mathrm{Al}>\mathrm{V}^{3+}$, the ideal formula of dellagiustaite is therefore $\mathrm{V}^{2+} \mathrm{Al}_{2} \mathrm{O}_{4}$, which require $\mathrm{Al}_{2} \mathrm{O}_{3} 60.25 \mathrm{wt} . \%$ and $\mathrm{VO} 39.75 \mathrm{wt} . \%$. However, as discussed below, the $\mathrm{V}^{3+}$ abundance is important for cation ordering and other features. If a crystal with composition $\mathrm{V}^{3+}>\mathrm{Al}$ were to be found, it would represent a successive member of the spinel subgroup, however with a new root-name. Dellagiustaite can be slightly zoned due to limited $\mathrm{V}_{-1}^{2+} \mathrm{Mg}$ substitution in the crystals from the type locality (Table 1), whereas significant variation is observed in samples from Israel (Table 3).

Table 2. Representative chemical compositions (in wt.\%) of phases associated with dellagiustaite in samples from Sierra de Comechingones.

\begin{tabular}{|c|c|c|c|c|c|c|c|c|c|c|}
\hline & Dgs * & Spinel & Spinel & Spinel & Grs *** & Grs & $\mathrm{Hib}$ & Hib **** & $\begin{array}{c}\mathrm{Ca}_{2} \mathrm{Al}_{3} \\
\mathrm{O}_{6} \mathrm{~F}\end{array}$ & $\mathbf{P v} * *$ \\
\hline Rock/Point & 12794B-2 & 12794B-7 & 12794B-10 & 12794B-11 & 12794B-19 & 12794B-5 & 12794B-4 & 12794B-6 & 12794B-8 & 12794B-12 \\
\hline $\mathrm{SiO}_{2}$ & 0.02 & 0.04 & 0.00 & 0.04 & 0.14 & 0.06 & 0.03 & 0.09 & 1.16 & 3.29 \\
\hline $\mathrm{TiO}_{2}$ & 0.73 & 0.00 & b.d.l. & b.d.l. & 0.01 & b.d.l. & 0.09 & 0.35 & 0.13 & 35.16 \\
\hline $\mathrm{Al}_{2} \mathrm{O}_{3}$ & 32.63 & 39.61 & 38.47 & 50.51 & 77.35 & 77.35 & 90.12 & 85.24 & 54.35 & 13.46 \\
\hline VO & 23.50 & 16.68 & 10.71 & 3.83 & b.d.l. & b.d.l. & b.d.l. & b.d.l. & b.d.l. & 0.48 \\
\hline $\mathrm{CrO}$ & 1.14 & b.d.l. & b.d.l. & b.d.1. & b.d.l. & b.d.l. & b.d.l. & 0.00 & b.d.l. & b.d.l. \\
\hline $\mathrm{MnO}$ & 0.41 & 0.85 & 1.05 & 1.36 & 0.00 & b.d.l. & 0.05 & 0.01 & b.d.l. & b.d.l. \\
\hline $\mathrm{MgO}$ & 7.23 & 12.99 & 16.64 & 22.87 & 0.08 & 0.03 & 0.18 & 0.63 & 0.05 & 0.05 \\
\hline $\mathrm{CaO}$ & 0.57 & 0.80 & 0.91 & 0.68 & 21.65 & 21.84 & 8.50 & 8.41 & 36.33 & 38.74 \\
\hline $\mathrm{SrO}$ & b.d.l. & 0.06 & b.d.l. & 0.08 & b.d.l. & b.d.l. & b.d.l. & b.d.l. & b.d.l. & b.d.l. \\
\hline $\mathrm{Ce}_{2} \mathrm{O}_{3}$ & b.d.l. & b.d.l. & b.d.l. & b.d.l. & b.d.l. & b.d.l. & 0.12 & b.d.l. & 0.10 & b.d.l. \\
\hline $\mathrm{F}$ & b.d.l. & b.d.l. & b.d.l. & b.d.l. & b.d.l. & b.d.l. & b.d.l. & b.d.l. & 5.42 & b.d.l. \\
\hline TOTAL & 102.02 & 100.51 & 101.09 & 101.03 & 99.76 & 100.16 & 101.51 & 100.97 & 101.46 & 96.38 \\
\hline $\mathrm{O}=\mathrm{F}$ & 0.00 & 0.00 & 0.00 & 0.00 & 0.00 & 0.00 & 0.00 & 0.00 & 2.28 & 0.00 \\
\hline TOTAL & 102.02 & 100.51 & 101.09 & 101.03 & 99.76 & 100.16 & 101.51 & 100.97 & 99.18 & 96.38 \\
\hline $\mathrm{Si}$ & 0.00 & 0.00 & 0.00 & 0.00 & 0.01 & 0.00 & 0.00 & 0.01 & 0.05 & 0.07 \\
\hline $\mathrm{Ti}^{4+}$ & 0.02 & 0.00 & 0.00 & 0.00 & 0.00 & 0.00 & 0.01 & 0.03 & 0.00 & 0.60 \\
\hline $\mathrm{Al}$ & 1.12 & 1.32 & 1.26 & 1.54 & 3.96 & 3.96 & 11.73 & 11.31 & 2.99 & 0.36 \\
\hline $\mathrm{Ti}^{3+}$ & 0.01 & 0.02 & 0.01 & 0.01 & 0.00 & 0.00 & 0.00 & 0.00 & 0.00 & 0.00 \\
\hline $\mathrm{Cr}^{3+}$ & 0.00 & 0.00 & 0.00 & 0.00 & 0.00 & 0.00 & 0.00 & 0.00 & 0.00 & 0.00 \\
\hline Sum & 3.01 & 2.99 & 3.00 & 3.00 & 5.01 & 5.02 & 13.00 & 13.03 & 5.18 & 2.10 \\
\hline $\mathrm{Ba}$ & 0.00 & 0.00 & 0.00 & 0.00 & 0.00 & 0.00 & 0.00 & 0.00 & 0.00 & 0.00 \\
\hline $\mathrm{Sr}$ & 0.00 & 0.00 & 0.00 & 0.00 & 0.00 & 0.00 & 0.00 & 0.00 & 0.00 & 0.00 \\
\hline $\mathrm{La}$ & 0.00 & 0.00 & 0.00 & 0.00 & 0.00 & 0.00 & 0.00 & 0.00 & 0.00 & 0.00 \\
\hline $\mathrm{Ce}^{3+}$ & 0.00 & 0.00 & 0.00 & 0.00 & 0.00 & 0.00 & 0.00 & 0.00 & 0.00 & 0.00 \\
\hline F & 0.00 & 0.00 & 0.00 & 0.00 & 0.00 & 0.00 & 0.00 & 0.00 & 0.80 & 0.00 \\
\hline
\end{tabular}

Notes: ${ }^{*} \mathrm{dgs}$, dellagiustaite; ${ }^{* *} \mathrm{pv}$, high-Al perovskite, grains are too small for the electron probe analyses; *** grs, grossite; ${ }^{* * * *}$ hib, hibonite; ${ }^{+}$No. Oxy, number of oxygen atoms per formula unit used for normalization. Spinel grains: \#2 rim of V-alloy; \#7; \#10 core and \#11 rim of a single idiomorphic grain in grossite. 
Table 3. Representative average chemical analyses (in wt.\%) for dellagiustaite, hibonite and grossite from Mt Carmel.

\begin{tabular}{|c|c|c|c|c|c|c|c|c|c|c|c|c|}
\hline \multirow{3}{*}{$\begin{array}{l}\text { Mineral } \\
\text { n. Points } \\
\text { No. Oxy }\end{array}$} & \multicolumn{4}{|c|}{ Dellagiustaite } & \multicolumn{4}{|c|}{ Hibonite } & \multicolumn{4}{|c|}{ Grossite } \\
\hline & 15 & Min. & Max. & Sd. & 3 & Min. & Max. & Sd. & 5 & Min. & Max. & Sd. \\
\hline & 4 & & & & 19 & & & & 7 & & & \\
\hline $\mathrm{SiO}_{2}$ & b.d.l. & & & & b.d.l. & & & & 0.05 & 0.00 & 0.27 & 0.12 \\
\hline $\mathrm{Al}_{2} \mathrm{O}_{3}$ & 34.45 & 27.00 & 37.79 & 3.12 & 85.59 & 82.37 & 87.73 & 2.84 & 77.06 & 76.55 & 77.34 & 0.30 \\
\hline $\mathrm{TiO}_{2}$ & b.d.l. & & & & b.d.l. & & & & b.d.l. & & & \\
\hline $\mathrm{Cr}_{2} \mathrm{O}_{3}$ & 0.66 & 0.00 & 2.72 & 0.89 & b.d.l. & & & & b.d.l. & & & \\
\hline $\mathrm{MnO}$ & 0.33 & 0.00 & 1.01 & 0.34 & b.d.l. & & & & b.d.l. & & & \\
\hline $\mathrm{V}_{2} \mathrm{O}_{3}$ & 31.27 & 28.51 & 36.99 & 2.27 & 5.91 & 3.67 & 9.60 & 3.22 & 0.82 & 0.64 & 1.07 & 0.16 \\
\hline $\mathrm{VO}$ & 21.42 & 13.65 & 30.26 & 4.83 & & & & & & & & \\
\hline $\mathrm{MgO}$ & 8.61 & 2.21 & 13.95 & 3.42 & 0.10 & 0.00 & 0.31 & 0.18 & b.d.l. & & & \\
\hline $\mathrm{CaO}$ & 0.66 & 0.28 & 0.83 & 0.15 & 8.18 & 7.91 & 8.60 & 0.37 & 22.05 & 21.80 & 22.16 & 0.15 \\
\hline $\mathrm{Na}_{2} \mathrm{O}^{\sim}$ & b.d.l. & & & & b.d.l. & & & & 0.02 & 0.00 & 0.10 & 0.04 \\
\hline $\mathrm{K}_{2} \mathrm{O}$ & b.d.l. & & & & 0.22 & 0.00 & 0.65 & 0.37 & b.d.l. & & & \\
\hline TOTAL & 97.40 & & & & 100.00 & & & & 100.00 & & & \\
\hline $\mathrm{Si}$ & 0.00 & & & & 0.00 & & & & 0.00 & & & \\
\hline $\mathrm{Ti}^{4+}$ & 0.00 & & & & 0.00 & & & & 0.00 & & & \\
\hline $\mathrm{V}^{3+}$ & 0.76 & & & & 0.54 & & & & 0.03 & & & \\
\hline $\mathrm{V}^{2+}$ & 0.58 & & & & 0.00 & & & & 0.00 & & & \\
\hline $\mathrm{Al}$ & 1.23 & & & & 11.44 & & & & 3.95 & & & \\
\hline $\mathrm{Cr}^{3+}$ & 0.02 & & & & 0.00 & & & & 0.00 & & & \\
\hline $\mathrm{Mn}^{2+}$ & 0.01 & & & & 0.00 & & & & 0.00 & & & \\
\hline $\mathrm{Ca}$ & 0.02 & & & & 0.99 & & & & 1.03 & & & \\
\hline $\mathrm{Mg}$ & 0.39 & & & & 0.02 & & & & 0.00 & & & \\
\hline $\mathrm{Na}$ & 0.00 & & & & 0.00 & & & & 0.00 & & & \\
\hline K & 0.00 & & & & 0.03 & & & & 0.00 & & & \\
\hline Sum & 3.00 & & & & 13.02 & & & & 5.01 & & & \\
\hline
\end{tabular}

Along with dellagiustaite, other spinel grains in samples from the same locality can occur and they show zonation from V-rich cores (close in composition to dellagiustaite), and increasing $\mathrm{Mg}$ and $\mathrm{Al}$ towards the rim of the crystals, suggesting that substitution of $\mathrm{V}_{-1}^{3+} \mathrm{Mg}$ is more pronounced than $\mathrm{V}_{-1}^{3+} \mathrm{Al}$ (Table 2). In Sierra de Comechingones, hibonite is rich in $\mathrm{V}^{3+}$ (ca. $0.21-0.24$ apfu), while grossite is depleted in $\mathrm{V}^{3+}(<0.03$ apfu).

At Mt Carmel, dellagiustaite is generally richer in $\mathrm{Mg}$ and is highly zoned with rims being richer in $\mathrm{Mg}$ and poorer in $\mathrm{V}^{2+}$, while $\mathrm{V}^{3+}$ and $\mathrm{Al}$ maintain an almost constant ratio. Smaller grains are richer in $\mathrm{V}^{2+}$, as are micrometer-sized inclusions included in hibonite and grossite.

Hibonite at Mt Carmel is rich in V and is zoned to rims that are depleted in Ca and richer in V, $\mathrm{K}$ and $\mathrm{Na}$ (Table 3). This phase, closely related to hibonite, is presently under study. Grossite at Mt Carmel is very similar in composition to that of Sierra de Comechingones (Table 3). Krotite (Table 4) and $\mathrm{Ca}_{2} \mathrm{Al}_{2} \mathrm{O}_{5}$ are also observed at $\mathrm{Mt}$ Carmel but not observed at Sierra de Comechingones yet.

In both localities, a high-Al perovskite phase is present as dendritic crystals (Tables 2 and 4). The substitution of $\mathrm{Ti}^{4+}$ by $\mathrm{V}^{3+}$ and $\mathrm{Al}$ can be coupled with some $\mathrm{H}$, involving contemporaneous vacancies at A sites. Further study is necessary but is hampered by the small size of these crystals. 
Table 4. Representative average chemical analyses (in wt.\%) for krotite, perovskite and (K,Na,V)-rich hibonite at Mt Carmel.

\begin{tabular}{|c|c|c|c|c|c|c|c|c|c|}
\hline \multirow{3}{*}{$\begin{array}{l}\text { Comment } \\
\text { n. Points } \\
\text { No. Oxy }\end{array}$} & \multicolumn{4}{|c|}{ Krotite } & \multirow{3}{*}{$\begin{array}{c}\text { Perovskite } \\
1 \\
3\end{array}$} & \multicolumn{4}{|c|}{$\mathrm{K}, \mathrm{Na}, \mathrm{V}-\mathrm{Rich}$ Hibonite } \\
\hline & 3 & Min. & Max. & Sd. & & 9 & Min. & Max. & Sd. \\
\hline & 4 & & & & & 19 & & & \\
\hline $\mathrm{SiO}_{2}$ & 0.68 & 0.55 & 0.77 & 0.12 & 0.32 & b.d.l. & & & \\
\hline $\mathrm{Al}_{2} \mathrm{O}_{3}$ & 63.14 & 62.64 & 63.47 & 0.43 & 3.52 & 85.10 & 83.27 & 87.60 & 1.49 \\
\hline $\mathrm{TiO}_{2}$ & b.d.l. & & & & 39.05 & b.d.l. & & & \\
\hline $\mathrm{Cr}_{2} \mathrm{O}_{3}$ & b.d.l. & & & & 1.37 & b.d.l. & & & \\
\hline $\mathrm{MnO}$ & b.d.l. & & & & b.d.l. & b.d.l. & & & \\
\hline $\begin{array}{c}\mathrm{V}_{2} \mathrm{O}_{3} \\
\mathrm{VO}\end{array}$ & 0.19 & 0.00 & 0.56 & 0.32 & $\begin{array}{r}5.77 \\
\text { b.d.l. }\end{array}$ & 5.04 & 3.67 & 5.77 & 0.78 \\
\hline $\mathrm{MgO}$ & b.d.l. & & & & b.d.l. & 2.24 & 0.68 & 4.45 & 1.27 \\
\hline $\mathrm{CaO}$ & 35.72 & 35.56 & 36.02 & 0.26 & 39.22 & 2.39 & 0.00 & 6.47 & 2.58 \\
\hline $\mathrm{Na}_{2} \mathrm{O}^{\sim}$ & b.d.l. & & & & b.d.l. & 1.24 & 0.19 & 2.84 & 1.04 \\
\hline $\mathrm{K}_{2} \mathrm{O}$ & b.d.l. & & & & b.d.l. & 3.93 & 1.89 & 6.84 & 1.57 \\
\hline TOTAL & 99.05 & & & & $89.25 *$ & 99.94 & & & \\
\hline $\mathrm{Si}$ & 0.02 & & & & 0.01 & 0.00 & & & \\
\hline $\mathrm{Ti}^{4+}$ & 0.00 & & & & 0.70 & 0.00 & & & \\
\hline $\mathrm{V}^{3+}$ & 0.00 & & & & 0.11 & 0.46 & & & \\
\hline $\mathrm{V}^{2+}$ & 0.00 & & & & 0.00 & 0.00 & & & \\
\hline $\mathrm{Al}$ & 1.96 & & & & 0.10 & 11.47 & & & \\
\hline $\mathrm{Cr}^{3+}$ & 0.00 & & & & 0.02 & 0.01 & & & \\
\hline $\mathrm{Mn}^{2+}$ & 0.00 & & & & 0.00 & 0.00 & & & \\
\hline $\mathrm{Ca}$ & 1.01 & & & & 0.99 & 0.29 & & & \\
\hline $\mathrm{Mg}$ & 0.00 & & & & 0.00 & 0.38 & & & \\
\hline $\mathrm{Na}$ & 0.01 & & & & 0.00 & 0.28 & & & \\
\hline K & 0.00 & & & & 0.00 & 0.57 & & & \\
\hline Sum & 2.98 & & & & $1.93^{* *}$ & 12.61 & & & \\
\hline
\end{tabular}

\section{X-ray Crystallography}

X-ray diffraction data for dellagiustaite were obtained by Debye-Scherrer geometry using an Oxford Diffraction Xcalibur diffractometer at the Department of Earth Sciences, University of Milan, Milan, Italy, operating at $50 \mathrm{kV}$ and $30 \mathrm{~mA}$, with a monochromatized $\mathrm{MoK} \alpha$ radiation and equipped with a CCD detector at $80 \mathrm{~mm}$ from the sample position. The one-dimensional pattern was refined by the Le Bail method using JANA2006 [19]. Indexed $d$ values and relative peak heights above background are given in Table 5. Refined cell parameters are $a=8.1877(10) \AA, V=548.89(6) \AA^{3}$.

A small dellagiustaite fragment was extracted from the polished section. X-ray single-crystal intensity data were collected using the same instruments and conditions. A combination of $\omega / \varphi$ scans, with step scan $1^{\circ}$ and exposure time $30 \mathrm{~s}$ per frame at low theta angles, and duplicating counting time at high-theta angles, was used to maximize redundancy and data coverage. A second data collection was performed on a V-rich spinel grain coming from another Argentinian sample corresponding to the spinel composition \#7 reported in Table 2, collecting images at $20 \mathrm{~s}$ per frame. Crystal data and details of the intensity data collection and refinement are reported in Table 6.

The structure of dellagiustaite was refined using SHELX-97 [20] starting from the atomic coordinates of magnetite. Scattering curves for fully ionized chemical species were used at cation sites; neutral vs. ionized scattering curves were used at the anion sites. This strategy allowed accounting for the ionization of anions. Scattering curves were taken from the International Tables for X-ray Crystallography [21]. The Fourier difference map did not reveal any maximum over $0.28 e^{-} \AA^{3}$. Refined atom coordinates and equivalent isotropic displacement parameters are reported in Table 7. Selected interatomic distances and bond angles are given in Table 8. Crystallographic information files and lists of observed and calculated structure factors for both crystals are available as Supplementary Materials (Files: dellagiustaite.cif/.fcf and 12794B.cif/.fcf). 
Table 5. X-ray powder diffraction pattern for dellagiustaite (reflections with $I>3 \%$ ). Observed interplanar spacings $\left(d_{\text {obs }}\right.$ in $\AA$ ) and calculated interplanar spacings $\left(d_{\text {calc }}\right.$ in $\AA$ ) and observed intensities (I) are reported.

\begin{tabular}{cccccc}
\hline $\mathbf{d}_{\text {obs }}$ & $\mathbf{d}_{\text {calc }}$ & $\mathbf{I}$ & $\mathbf{h}$ & $\mathbf{k}$ & $\mathbf{1}$ \\
\hline 4.727 & 4.731 & 5 & 1 & 1 & 1 \\
2.895 & 2.897 & 5 & 2 & 0 & 2 \\
2.469 & 2.471 & 19 & 1 & 1 & 3 \\
$\mathbf{2 . 0 4 7}$ & $\mathbf{2 . 0 4 9}$ & $\mathbf{5 8}$ & $\mathbf{0}$ & $\mathbf{0}$ & $\mathbf{4}$ \\
$\mathbf{1 . 5 7 6}$ & $\mathbf{1 . 5 7 7}$ & $\mathbf{3 8}$ & $\mathbf{3}$ & $\mathbf{3}$ & $\mathbf{3}$ \\
& & & 1 & 1 & 5 \\
$\mathbf{1 . 4 4 7}$ & $\mathbf{1 . 4 4 9}$ & $\mathbf{1 0 0}$ & $\mathbf{4}$ & $\mathbf{0}$ & $\mathbf{4}$ \\
1.249 & 1.250 & 8 & 3 & 3 & 5 \\
1.234 & 1.235 & 6 & 2 & 2 & 6 \\
$\mathbf{1 . 1 8 2}$ & $\mathbf{1 . 1 8 3}$ & $\mathbf{2 7}$ & $\mathbf{4}$ & $\mathbf{4}$ & $\mathbf{4}$ \\
1.066 & 1.067 & 18 & 3 & 1 & 7 \\
& & & 5 & 3 & 5 \\
$\mathbf{1 . 0 2 3}$ & $\mathbf{1 . 0 2 4}$ & $\mathbf{8 7}$ & $\mathbf{0}$ & $\mathbf{0}$ & $\mathbf{8}$ \\
0.945 & 0.946 & 16 & 5 & 1 & 7 \\
& & & 5 & 5 & 5 \\
0.939 & 0.940 & 5 & 6 & 2 & 6 \\
$\mathbf{0 . 9 1 5}$ & $\mathbf{0 . 9 1 6}$ & $\mathbf{2 1}$ & $\mathbf{4}$ & $\mathbf{0}$ & $\mathbf{8}$ \\
0.873 & 0.874 & 18 & 6 & 4 & 6 \\
0.858 & 0.859 & 8 & 3 & 1 & 9 \\
$\mathbf{0 . 8 3 6}$ & $\mathbf{0 . 8 3 6}$ & $\mathbf{3 5}$ & $\mathbf{4}$ & $\mathbf{4}$ & $\mathbf{8}$ \\
0.803 & 0.804 & 12 & 6 & 2 & 8 \\
& & & 2 & 0 & 10 \\
\hline
\end{tabular}

Table 6. Crystal and experimental details for dellagiustaite and V-rich spinel from Sierra de Comechingones.

\begin{tabular}{|c|c|c|}
\hline \multicolumn{3}{|c|}{ Crystal Data } \\
\hline & dellagiustaite & V-rich spinel \\
\hline Crystal size $\left(\mathrm{mm}^{3}\right)$ & $0.149 \times 0.137 \times 0.095$ & $0.120 \times 0.100 \times 0.060$ \\
\hline Cell setting, space group & Cubic, $F d \overline{3} m$ & Cubic, $F d \overline{3} m$ \\
\hline$a(\AA)$ & $8.1950(1)$ & $8.1754(2)$ \\
\hline$V\left(\AA^{3}\right)$ & $550.36(1)$ & $546.42(2)$ \\
\hline Z & 8 & 8 \\
\hline \multicolumn{3}{|c|}{ Data Collection and Refinement } \\
\hline Radiation, wavelength $(\AA)$ & Mo $K \alpha, \lambda=0.71073$ & Mo $K \alpha, \lambda=0.71073$ \\
\hline Temperature $(\mathrm{K})$ & 293 & 293 \\
\hline $2 \theta_{\max }\left({ }^{\circ}\right)$ & 72.1 & 72.2 \\
\hline Measured reflections & 3605 & 3579 \\
\hline Unique reflections & 85 & 85 \\
\hline Reflections with $F_{\mathrm{o}}>4 \sigma\left(F_{\mathrm{o}}\right)$ & 81 & 77 \\
\hline$R_{\text {int }}$ & 0.0194 & 0.0337 \\
\hline$R \sigma$ & 0.0055 & 0.0092 \\
\hline & $-13 \leq h \leq 13$ & $-13 \leq h \leq 13$ \\
\hline Range of $h, k, l$ & $\begin{array}{l}-10 \leq k \leq 10 \\
-12 \leq l \leq 12\end{array}$ & $\begin{array}{l}-10 \leq k \leq 10 \\
-13 \leq l \leq 13\end{array}$ \\
\hline$R\left(F_{\mathrm{o}}>4 \sigma\left(F_{\mathrm{o}}\right)\right)$ & 0.0140 & $0 . \overline{0} 16 \overline{6}$ \\
\hline$R$ (all data) & 0.0151 & 0.0215 \\
\hline $\mathrm{w} R\left(\right.$ on $\left.F^{2}\right)$ & 0.0339 & 0.0343 \\
\hline GooF & 1.245 & 1.402 \\
\hline Number of least-square parameters & 11 & 11 \\
\hline Maximum and minimum residuals $\left(e / \AA^{3}\right)$ & $\begin{array}{l}0.29 \text { (at } 0.74 \text { from } M) \\
-0.56 \text { (at } 0.68 \text { from } M)\end{array}$ & $\begin{array}{l}0.30 \text { (at } 0.83 \text { from } M), \\
-0.27 \text { (at } 1.66 \text { from } O)\end{array}$ \\
\hline
\end{tabular}


Table 7. Atom, site occupancies (site occ.), refined atom coordinates and equivalent isotropic displacement parameters for dellagiustaite and V-rich spinel.

\begin{tabular}{|c|c|c|c|c|c|}
\hline Site & Site Occ. & $x / a$ & $y / b$ & $z / c$ & $\mathbf{U}_{e q}$ \\
\hline \multicolumn{6}{|c|}{ Dellagiustaite } \\
\hline$T$ & $\begin{array}{l}\mathrm{Al}^{3+} 0.96(2) \\
\mathrm{V}^{3+} 0.04(2)\end{array}$ & $1 / 8$ & $1 / 8$ & $1 / 8$ & $0.0099(4)$ \\
\hline$M$ & $\begin{array}{l}\mathrm{Al}^{3+} 0.04(3) \\
\mathrm{V}^{3+} 0.96(3)\end{array}$ & $1 / 2$ & $1 / 2$ & $1 / 2$ & $0.0154(2)$ \\
\hline $\mathrm{O}$ & $\begin{array}{l}\mathrm{O}^{0} 0.90(17) \\
\mathrm{O}^{=} 0.10(17)\end{array}$ & $0.25054(11)$ & $0.25054(11)$ & $0.25054(11)$ & $0.0108(5)$ \\
\hline \multicolumn{6}{|c|}{ V-rich spinel } \\
\hline$T$ & $\begin{array}{l}\mathrm{Al}^{3+} 0.97(2) \\
\mathrm{V}^{3+} 0.03(2)\end{array}$ & $1 / 8$ & $1 / 8$ & $1 / 8$ & $0.0101(3)$ \\
\hline$M$ & $\begin{array}{l}\mathrm{Al}^{3+} 0.44(2) \\
\mathrm{V}^{3+} 0.56(2)\end{array}$ & $1 / 2$ & $1 / 2$ & $1 / 2$ & $0.0111(2)$ \\
\hline $\mathrm{O}$ & $\begin{array}{l}\mathrm{O}^{0} 0.82(13) \\
\mathrm{O}^{=} 0.18(13)\end{array}$ & $0.25612(10)$ & $0.25612(10)$ & $0.25612(10)$ & $0.0129(5)$ \\
\hline
\end{tabular}

Table 8. Selected interatomic distances $(\AA)$ in dellagiustaite and V-rich spinel.

\begin{tabular}{ccc}
\hline & Dellagiustaite & V-Rich Spinel \\
\hline$T-\mathrm{O} \times 4$ & $1.782(2)$ & $1.8567(14)$ \\
$M-\mathrm{O} \times 6$ & $2.0445(9)$ & $1.9951(7)$ \\
\hline
\end{tabular}

The anisotropic displacement parameters refined for the $M$ sites showed a particular behavior, depicted as a prolate thermal ellipsoid. Therefore, several tests were undertaken to explore a possible decrease of symmetry but none reported a better fit for solving this feature. The prolate character of ellipsoid was reduced (although not removed) in the V-rich spinel and therefore it could be related to the V content.

\section{Results and Discussion}

\subsection{Description of the Crystal Structure}

Site populations for dellagiustaite and V-rich spinel have been derived from the unit formula (for V-rich spinel we used the analysis \#7 from Table 2) and are reported in Table 9. The refined $\langle M-O\rangle$ distance of $2.045 \AA$ is somewhat longer than the expected $2.038 \AA$, possibly due to the presence of $\mathrm{V}^{2+}$ at the octahedral sites, as estimated by WDS-EMPA; in fact, the values for $\mathrm{V}^{2+}-\mathrm{O}$ in octahedral coordination were taken from the $\mathrm{VO}$ structure [22], whereas the other bond distances are taken from [23] except for $\mathrm{Ti}^{3+}-\mathrm{O}$, which was taken from the $\mathrm{Ti}_{2} \mathrm{O}_{3}$ structure [24]. The $\mathrm{V}^{2+}-\mathrm{O}$ value of 2.129(4) $\AA$, obtained statistically in [25], is certainly too high and leads to a higher disagreement (calculated $M-O$ mean bond length using such value would be $2.069 \AA$ ). Sutton et al. [8] found an almost zero intensity for the pre-edge peak in $\mathrm{V}^{2+}$ glasses by XANES and concluded that it is likely that $\mathrm{V}^{2+}$ occurs in a highly symmetrical octahedral site in these glasses. Therefore, we have kept both $\mathrm{V}^{3+}$ and $\mathrm{V}^{2+}$ in octahedral coordination when calculating the distribution of cations among the sites. Overall, the agreement in terms of site scattering (in electrons per site, eps) with the chemical analyses is within $3 \%$ and, for mean bond lengths, the difference is about $0.006 \AA$. While the V-rich spinel shows an intermediate degree of inversion $(i=0.53)$, dellagiustaite is fully inverted.

Dellagiustaite is therefore an inverse spinel. Besides being $\mathrm{V}^{3+}$-rich, it cannot be classified as a "vanadium coulsonite" because that would require $\mathrm{Al}<\mathrm{V}^{3+}$. In addition, coulsonite is a normal spinel. We are looking carefully through our samples in search for spinel grains with higher V-contents, which 
would require disordering of $\mathrm{V}^{3+}$ over $T$ - and $M$-sites and would represent a new spinel species with a new root-name.

Table 9. Site occupancies (site scattering (s.s.) and electrons per site (eps)) and mean bond-lengths (m.b.l., Å) for dellagiustaite and V-rich spinel.

\begin{tabular}{|c|c|c|c|c|c|}
\hline \multirow{2}{*}{ Site } & \multirow{2}{*}{ Site Occupancies (apfu) } & \multicolumn{2}{|c|}{ s.s. (eps) } & \multicolumn{2}{|c|}{ m.b.l. (Å) } \\
\hline & & Refined & Calculated & Refined & Calculated \\
\hline \multicolumn{6}{|c|}{ Dellagiustaite } \\
\hline$T$ & $1 \mathrm{Al}^{3+}$ & $13.4(2)$ & 13 & $1.782(2)$ & 1.774 \\
\hline$M$ & $0.88 \mathrm{~V}^{3+}+0.91 \mathrm{~V}^{2+}+0.09 \mathrm{Al}^{3+}+0.08 \mathrm{Mg}+0.03 \mathrm{Ti}^{3+}+0.01 \mathrm{Mn}^{2+}$ & 22.51(3) & 21.78 & $2.045(5)$ & 2.038 \\
\hline \multicolumn{6}{|c|}{ V-Rich Spinel } \\
\hline$T$ & $0.53 \mathrm{Al}^{3+}+0.47 \mathrm{Mg}$ & $13.3(2)$ & 12.53 & $1.857(2)$ & 1.864 \\
\hline$M$ & $0.80 \mathrm{Al}^{3+}+0.64 \mathrm{~V}^{3+}+0.43 \mathrm{~V}^{2+}+0.08 \mathrm{Mg}+0.03 \mathrm{Ti}^{3+}+0.02 \mathrm{Ca}$ & $18.6(2)$ & 18.19 & 1.995(1) & 1.989 \\
\hline
\end{tabular}

The behavior of prolate thermal ellipsoids of the $M$ site would seem to show that the spinel structure has some difficulty in hosting $\mathrm{V}$ cations with two valences, when $\mathrm{V}$ is a dominant component. In fact, Bosi et al. [26] found a limited accommodation of $\mathrm{V}^{4+}$ in the $\mathrm{MgAl}_{2} \mathrm{O}_{4}-\mathrm{Mg}_{2} \mathrm{~V}^{4+} \mathrm{O}_{4}$ series and concluded that the distribution of $\mathrm{V}$ valences in spinels does not exclusively reflect oxygen fugacity, but also depends on the activity and solubility of all chemical components in the crystallization environment. Bosi et al. [26] also concluded that the inverse cation distribution can influence the incorporation of $\mathrm{V}^{4+}$, being favored in inverse spinels. Apparently, this is also observed for $\mathrm{V}^{2+}$ in our samples.

On the other hand, Sutton et al. [8] observed a slight compositional dependence of the oxidation state of $\mathrm{V}$ with the composition of glasses, with more highly reduced $\mathrm{V}$ in low-Ca glasses. The zoning observed in spinel (Table 2) seems to support this hypothesis as zoning encompasses an oxidation of $\mathrm{V}$ as well as the crystallization of more Ca-rich phases due to the fractional crystallization of more Al-rich phases like hibonite.

It is worth noting that ${ }^{T} \mathrm{Al}^{M}\left(\mathrm{~V}^{2+} \mathrm{V}^{3+}\right) \mathrm{O}_{4}$ is a synthetic compound that has been reported to show a charge ordering (CO) phase transition with rhombohedral distortion along [111] of the cubic cell ( $\alpha$ decreases from $60^{\circ}$ to ca. $59^{\circ}$ below $427^{\circ} \mathrm{C}$ ) [27]. The CO structure is converted at $P>23 \mathrm{GPa}$ to the cubic structure, which does not revert back to the rhombohedral form on decompression [28]. In the rhombohedral phase, three distinct type of sites are observed for vanadium: $V 1, V 2$ and $V 3$. Molecular groups made of six $V 3$-sites and one $V$ 2-sites form heptamers with short V-V distances $(V 2-V 3=2.8238(2) \AA$ and $V 3-V 3=2.6740(1) \AA)$ and antibonding distances $(V 3-V 3=3.0850(1) \AA)$, while $V 1-V 3$ are also in a non-bonding configuration of 3.0001(2) $\AA$ [28]. Recently, this model has been discussed proposing alternatively the presence of trimers $\left(\mathrm{V}_{3}^{9+}\right)$ and tetramers $\left(\mathrm{V}_{4}^{8+}\right)$ rather than $\mathrm{V}_{7}^{17+}$ heptamers, by allowing the shift of $V 2$ atoms along [111] in a polar $R 3 m$ model obtained by PDF using X-ray diffraction powder data [29]. The trimers were also considered by Talanov et al. [30] in their density functional theory study of the crystal chemical analysis of $\mathrm{V}-\mathrm{O}$ bond lengths of ${ }^{T} \mathrm{Al}^{M}\left(\mathrm{~V}^{2+} \mathrm{V}^{3+}\right) \mathrm{O}_{4}$.

In dellagiustaite, we observed a cubic structure at room $T$, with no evidence of superlattice reflections at $\frac{1}{2}$ [111]. In the cubic model the V-V distances are indeed all equivalent (2.89738(5) $\AA$ in this work; $2.92 \AA$ in [27]). However, the elongated thermal ellipsoids along [111] in the mixed tetrahedra-octahedra layers, and along (100) in the octahedra layers (Figure 6c-e) are an indication of static disorder at the $M$-sites, possibly indicating a sort of frustrated charge ordering. Our single-crystal data allowed an accurate determination of the atomic displacement parameters (adp); this is not possible with the previous experimental data, all of which are from powdered synthetic run products.

In dellagiustaite, charge ordering possibly could be frustrated at room $T$ due to the presence of minor amounts of $\mathrm{Al}$ at the $M$ sites. In fact, it has been described that doping of $\mathrm{AlV}_{2} \mathrm{O}_{4}$ by $\mathrm{Cr}^{3+}$ frustrates the $\mathrm{CO}$ with the generation of microdomains (as small as $10-20 \mathrm{~nm}$ ) observed by electron 
diffraction [31]. It could be worthwhile studying dellagiustaite by electron diffraction to test for the presence of $\mathrm{CO}$ domains.

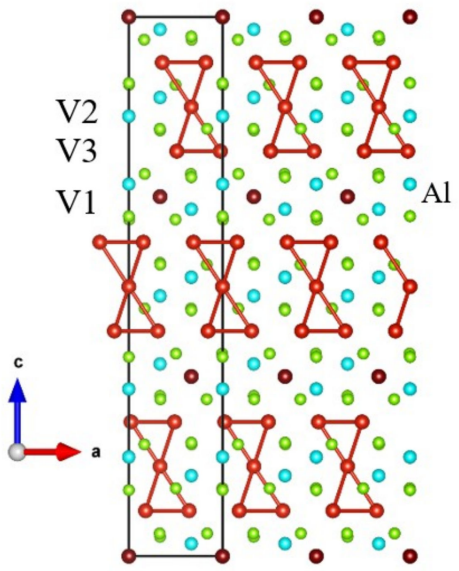

(a)

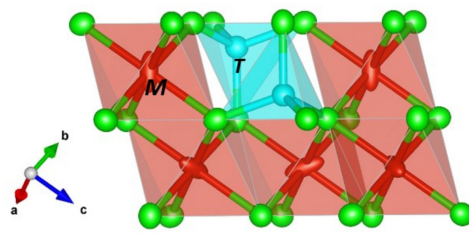

(d)

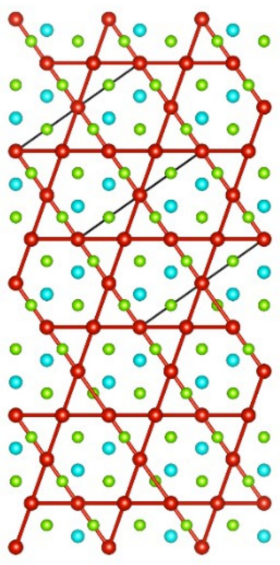

(b)

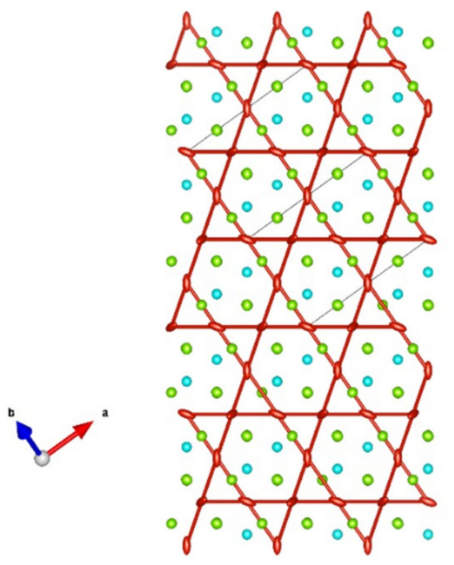

(c)

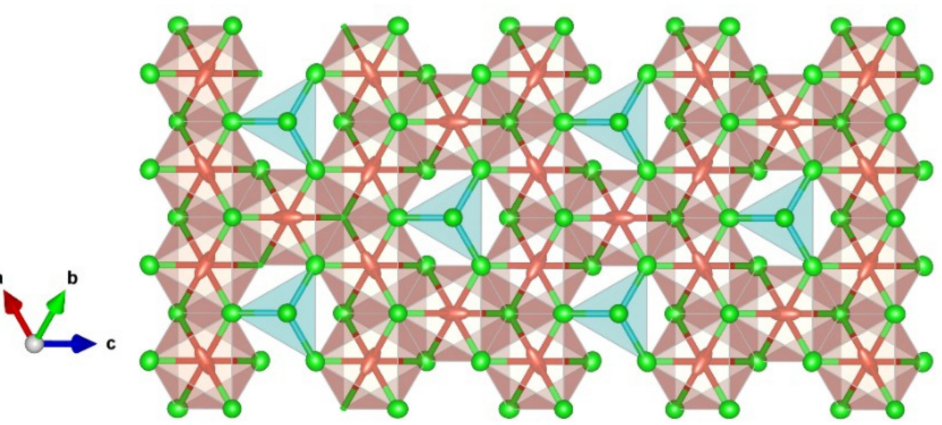

(e)

Figure 6. The structure of AlV2O4 (redrawn from [28] (a,b) compared with dellagiustaite in this work (c-e)): (a) the rhombohedral phase projected onto (0-10); (b) the cubic frustrated phase projected onto (0-11); (c) dellagiustaite projected onto (0-11); (d) dellagiustaite showing local coordination details and static disorder of $\mathrm{V}$ atom positions that alternate along [111]; and (e) the structure of dellagiustaite projected onto (111) showing the disorder of $\mathrm{V}$ atoms within the plane, related to statistical configurations of three V-bonded and three anti-bonded groups. Thermal ellipsoids plotted at $95 \%$ probability with Vesta 3.0 [32]. Al in four-fold coordination (blue navy) and vanadium (2+ and $3+$ ) in six-fold coordination (red). Green $=\mathrm{O}$. There are three symmetrically different $\mathrm{V}$ sites in the rhombohedral phase but only one in the cubic. The single crystal data on dellagiustaite shows the adp values of $\mathrm{V}$ atoms compatible with static disorder (domains?) or dynamic disorder, in the cubic phase. The disorder resembles the low-T configuration.

\subsection{Conditions of Formation}

The genesis of dellagiustaite at Sierra de Comechingones is difficult to decipher, mainly because of the missing information about the exact location of the outcrop and the related rocks. Furthermore, the paragenesis is rather uncommon: the rock is mostly composed of $\mathrm{Al}_{2} \mathrm{O}_{3}$ and $\mathrm{CaO}$, with minor other components (mostly $\mathrm{V}_{2} \mathrm{O}_{3}$ and even lesser amounts of $\mathrm{TiO}_{2}, \mathrm{Na}_{2} \mathrm{O}$ and F). The almost complete absence of $\mathrm{SiO}_{2}$ also makes the paragenesis rather unusual. The dominant mineral phases are hibonite and grossite. Hibonite is a constituent of some refractory Calcium-Aluminum Inclusions (CAIs) in carbonaceous meteorites, commonly accompanied by grossite and spinel, crystallized early in the evolution of the solar nebula. Grossite has been found in very few localities but is also a relatively frequent mineral phase in CAIs. However, other aspects are even more puzzling. In particular, the 
presence of almost pure vanadium alloys with requires extremely reducing conditions $(\Delta \mathrm{IW},-9$, where IW = iron-wustite buffer).

The fact that very similar rocks have been recently described from Mt Carmel (northern Israel) makes its origin even more interesting. The rocks in Israel contain super-reduced mineral assemblages, which crystallized from high- $T$ melts trapped in corundum aggregates (micro-xenoliths) ejected from Cretaceous volcanoes of picritic tholeiite composition $[9,10]$. In these rocks, highly reduced minerals have been described, such as moissanite (up to $4 \mathrm{~mm}$ long; larger than those reported in [33]), tistarite, khamrabaevite, and gupeiite along with native vanadium, and have been interpreted as the result of interaction between deep-seated magmas and $\mathrm{CH}_{4} \pm \mathrm{H}_{2}$ fluids in volcanic plumbing systems, producing local ultra-reducing conditions [9-12]. The Argentinian rocks containing dellagiustaite are very similar to type-DF pockets in Mt Carmel, although, in the dellagiustaite-bearing rocks, the vanadium alloy is included in both hibonite and grossite and has tubular-cylindrical shapes. In addition, corroded laths of corundum included in hibonite have been observed in some Mt Carmel material, but not in the Argentinian samples; the rock containing dellagiustaite may represent a more calcic composition.

Hibonite and grossite are rather rare minerals in terrestrial occurrences. Hibonite originally was described in the Esiva alluvial deposits (Madagascar [34]), probably derived from nearby deposits of thorianite bearing skarns in granulite belts of Madagascar and Tanzania [35]. In the Madagascar occurrences, hibonite replaces corundum and spinel in corundum + spinel + scapolite assemblages. Another occurrence of hibonite has been reported in Ca-Mg-Al granulitic xenoliths in basanites of the Kwa Nthuku volcano in the northwestern part of the Chyulu Hills, a volcanic field at the eastern flank of the Kenya rift some 150-200 km east of the rift axis, about $50 \mathrm{~km}$ NE of Mt. Kilimanjaro. In the $\mathrm{Ca}-\mathrm{Al}$ granulites, hibonite ( \pm spinel) are the earliest, possibly igneous, minerals in the crystallization sequence [36]. Hibonite has been also reported as tabular crystals up to $3 \mathrm{~cm}$ across in calcitic marbles from the Tashelga-Malzaskaya region in Siberia [37]. In such localities, metamorphic hibonites are notably high in $\mathrm{Fe}^{3+}$, and coexist with V-rich minerals (goldmanite, tashelgite, and mukhinite). Hibonite has also been found in the alluvia of Myanmar, Mandalay Region, which has been used as a gemstone [38]. Grossite has been found on Earth only in the type locality, the Hatrurim Formation; the rest of the observed occurrences are in meteorites. Krotite previously has been observed only in Calcium-Aluminum Inclusions in meteorites [39].

If the origin of the type material is similar to the Mt Carmel rocks, a highly plausible locality is in one of the outcrops of the Neogene Volcanic Belt of San Luis (SLNVB) in the Pampean flat-slab segment, in particular in Sierra del Morro ( $\left.33^{\circ} 10^{\prime} \mathrm{S}, 66^{\circ} 24^{\prime} \mathrm{W}\right)$, in the Conlara Valley, which is closer to Sierra de Comechingones than to Sierras de San Luis. These volcanic materials are pyroclastic trachyandesites-trachydacites with shoshonitic to high $\mathrm{K}$ calc-alkaline character consistent with a subduction-related continental margin setting [40].

Supplementary Materials: The following are available online at http:/ /www.mdpi.com/2075-163X/9/1/4/s1, CIF: dellagiustaite, V-rich spinel.

Author Contributions: A.P. and R.P. provided the sample and asked for a study of the material; F.C. performed the X-ray single-crystal experiments and the electron microprobe analyses of the Argentinian samples; L.B. carried out the optical measurements; W.L.G. and S.E.M.G. carried out the analyses of Israeli samples; F.C. and L.B. analyzed the data; and F.C. wrote the paper with input from all coauthors.

Funding: This work was supported by a grant from the University of Milan research fund to young researchers PSR2017-PLOTTI to P. Lotti. This is contribution 1233 from the ARC Centre of Excellence for Core to Crust Fluid Systems (http:/ / www.ccfs.mq.edu.au) and 1227 in the GEMOC Key Centre (http:/ /www.gemoc.mq.edu.au), and is related to IGCP-662.

Acknowledgments: We thank Adam Pieczka and two anonymous referees for helping to improve the text, Fabio Marchesini for careful polished samples preparation and Andrea Risplendente for skillful technical support during EMPA analysis at the University of Milan. The Mt Carmel analytical data were obtained using instrumentation funded by DEST Systemic Infrastructure Grants, ARC LIEF, NCRIS/AuScope, industry partners and Macquarie University.

Conflicts of Interest: The authors declare no conflict of interest. 


\section{References}

1. Bosi, F.; Biagioni, C.; Pasero, M. Nomenclature and classification of the spinel supergroup. Eur. J. Mineral. 2018. [CrossRef]

2. Bosi, F.; Andreozzi, G.B. Chromium influence on $\mathrm{Mg}-\mathrm{Al}$ intracrystalline exchange in spinels and geothermometric implications. Am. Mineral. 2017, 102, 333-340. [CrossRef]

3. Carpenter, M.A.; Salje, E.K.H. Thermodynamics of nonconvergent cation ordering in minerals: II. Spinels and the orthopyroxene solid solution. Am. Mineral. 1994, 79, 1068-1083.

4. Kroll, H.; Schlenz, H.; Phillips, M.W. Thermodynamic modelling of non-convergent ordering in orthopyroxenes: A comparison of classical and Landau approaches. Phys. Chem. Miner. 1994, 21, 555-560. [CrossRef]

5. Hazen, R.M.; Yang, H. Effects of cation substitution and order-disorder on P-V-T equations of state of cubic spinels. Am. Mineral. 1999, 84, 1956-1960. [CrossRef]

6. Wong, J.; Lytle, F.W.; Messmer, R.P.; Maylotte, D.H. K-edge absorption spectra of selected vanadium compounds. Phys. Rev. B 1984, 30, 5596-5610. [CrossRef]

7. Keppler, H. Crystal field spectra and geochemistry of transition metal ions in silicate melts and glasses. Am. Mineral. 1992, 77, 62-75.

8. Sutton, S.R.; Karner, J.; Papike, J.; Delaney, J.S.; Shearer, C.; Newville, M.; Eng, P.; Rivers, M.; Dyar, M.D. Vanadium K edge XANES of synthetic and natural basaltic glasses and application to microscale oxygen barometry. Geochim. Cosmochim. Acta 2005, 69, 2333-2348. [CrossRef]

9. Griffin, W.L.; Gain, S.E.M.; Adams, D.T.; Huang, J.-X.; Saunders, M.; Toledo, V.; Pearson, N.J.; O’Reilly, S.Y. First terrestrial occurrence of tistarite $\left(\mathrm{Ti}_{2} \mathrm{O}_{3}\right)$ : Ultra-low oxygen fugacity in the upper mantle beneath Mount Carmel, Israel. Geology 2016, 44, 815-818. [CrossRef]

10. Xiong, Q.; Griffin, W.L.; Huang, J.X.; Gain, S.E.M.; Toledo, V.; Pearson, N.J.; O’Reilly, S.Y. Super-reduced mineral assemblages in "ophiolitic" chromitites and peridotites: The view from Mount Carmel. Eur. J. Mineral. 2017, 29, 557-570. [CrossRef]

11. Griffin, W.L.; Huang, J.-X.; Thomassot, E.; Gain, S.E.M.; Toledo, V.; O’Reilly, S.Y. Super-reducing conditions in ancient and modern volcanic systems: Sources and behaviour of carbon-rich fluids in the lithospheric mantle. Mineral. Petrol. 2018, 112, 101-114. [CrossRef]

12. Griffin, W.L.; Gain, S.E.M.; Huang, J.-X.; Saunders, M.; Shaw, J.; Toledo, V.; O'Reilly, S.Y. A terrestrial magmatic hibonite-grossite-vanadium assemblage: Desilication and extreme reduction in a volcanic plumbing system, Mt Carmel, Israel. Am. Mineral. 2019. [CrossRef]

13. Otamendi, J.E.; Demichelis, A.H.; Tibaldi, A.M.; De La Rosa, J.D. Genesis of aluminous and intermediate granulites: A case study in the Eastern Sierras Pampeanas, Argentina. Lithos 2006, 89, 66-88. [CrossRef]

14. Steenken, A.; Wemmer, K.; Martino, R.D.; López de Luchi, M.G.; Guereschi, A.; Siegesmund, S. Post-Pampean cooling and the uplift of the Sierras Pampeanas in the west of Córdoba (Central Argentina). Neues Jahrb. Geol. Palaontol. 2010, 256, 235-255. [CrossRef]

15. Jacques, J.K. The heats of formation of cuspidine, $3 \mathrm{CaO}, 2 \mathrm{SiO}_{2}, \mathrm{CaF}_{2}$, and the mineral phase, $3 \mathrm{CaO}_{3} 3 \mathrm{Al}_{2} \mathrm{O}_{3}$, $\mathrm{CaF}_{2}$. J. Chem. Soc. 1963, 9, 4297-4299. [CrossRef]

16. Xia, Z.; Molokeev, M.S.; Oreshonkov, A.S.; Atuchin, V.V.; Liu, R.-S.; Dong, C. Crystal and local structure refinement in $\mathrm{Ca}_{2} \mathrm{Al}_{3} \mathrm{O}_{6} \mathrm{~F}$ explored by X-ray diffraction and Raman spectroscopy. Phys. Chem. Chem. Phys. 2014, 16, 5952-5957. [CrossRef]

17. Andersen, T.; Griffin, W.L.; O'Reilly, S.Y. Primary sulphide melt inclusions in mantle-derived megacrysts and pyroxenites. Lithos 1987, 20, 279-294. [CrossRef]

18. Pouchou, J.L.; Pichoir, F. 'PAP' $\phi(\varrho Z)$ procedure for improved quantitative microanalysis. In Microbeam Analysis; Armstrong, J.T., Ed.; San Francisco Press: San Francisco, CA, USA, 1985; p. 104106.

19. Petricek, V.; Dusek, M.; Palatinus, L. Crystallographic Computing System JANA2006: General features. Z. Krist. Cryst. Mater. 2014, 229, 345-352.

20. Sheldrick, G.M. Crystal structure refinement with SHELXL. Acta Crystallogr. 2015, C71, 3-8.

21. International Tables for Crystallography. Volume C: Mathematical, Physical and Chemical Tables; Wilson, A.J.C., Ed.; Kluwer Academic: Dordrecht, The Netherland, 1992.

22. Hartmann, H.; Maessing, W. Elektrolyse in Phosphatschmelzen. IV. Über die Elektrolyse von Vanadin-, Niobund Tantaloxyd in Phosphatschmelzen. Z. Anorg. Allg. Chem. 1951, 266, 98-104. [CrossRef] 
23. Lavina, B.; Salviulo, G.; Della Giusta, A. Cation distribution and structure modelling of spinel solid solutions. Phys. Chem. Miner. 2002, 29, 10-18. [CrossRef]

24. Rice, C.E.; Robinson, W.R. Structural changes in the solid solution $\left(\mathrm{Ti}_{1-\mathrm{x}} \mathrm{V}_{\mathrm{x}}\right)_{2} \mathrm{O}_{3}$ as $\mathrm{x}$ varies from zero to one. J. Solid State Chem. 1977, 21, 145-154. [CrossRef]

25. Urusov, V.S.; Serezhkin, V.N. Distortion of $\mathrm{V}^{\mathrm{Z}+} \mathrm{O}_{\mathrm{n}}$ coordination polyhedra and parameters of the bond valence model for VO bonds in inorganic crystals. Crystallogr. Rep. 2009, 54, 190-194. [CrossRef]

26. Bosi, F.; Skogby, H.; Fregola, R.A.; Hålenius, U. Crystal chemistry of spinels in the system $\mathrm{MgAl}_{2} \mathrm{O}_{4}-\mathrm{MgV}_{2} \mathrm{O}_{4}-\mathrm{Mg}_{2} \mathrm{VO}_{4}$. Am. Mineral. 2016, 101, 580-586. [CrossRef]

27. Matsuno, K.; Katsufuji, T.; Mori, S.; Moritomo, Y.; Machida, A.; Nishibori, E.; Takata, M.; Sakata, M.; Yamamoto, N.; Takagi, H. Charge Ordering in the Geometrically Frustrated Spinel $\mathrm{AlV}_{2} \mathrm{O}_{4}$. J. Phys. Soc. Jpn. 2001, 70, 1456-1459. [CrossRef]

28. Kalavathi, S.; Raju, S.V.; Williams, Q.; Sahu, P.C.; Sastry, V.S.; Sahu, H.K. Pressure-induced frustration in charge ordered spinel $\mathrm{AlV}_{2} \mathrm{O}_{4}$. J. Phys. Condens. Matter 2013, 25, 292201. [CrossRef] [PubMed]

29. Browne, A.J.; Kimber, S.A.J.; Attfield, J.P. Persistent three- and four-atom orbital molecules in the spinel $\mathrm{AlV}_{2} \mathrm{O}_{4}$. Phys. Rev. Mater. 2017, 1, 052003. [CrossRef]

30. Talanov, M.V.; Shirokov, V.B.; Avakyan, L.A.; Talanov, V.M.; Borlakov, K.S. Vanadium clusters formation in geometrically frustrated spinel oxide $\mathrm{AlV}_{2} \mathrm{O}_{4}$. Acta Crystallogr. 2018, B74, 337-353. [CrossRef]

31. Horibe, Y.; Kurushima, K.; Mori, S.; Asada, T.; Koyama, Y.; Shingu, M.; Katsufuji, T. Doping effect on the charge ordering in $\mathrm{AlV}_{2} \mathrm{O}_{4}$. Phys. Rev. B 2005, 71, 052411. [CrossRef]

32. Momma, K.; Izumi, F. VESTA 3 for three-dimensional visualization of crystal, volumetric and morphology data. J. Appl. Crystallogr. 2011, 44, 1272-1276. [CrossRef]

33. Di Pierro, S.; Gnos, E.; Grobety, B.H.; Armbruster, T.; Bernasconi, S.M.; Ulmer, P. Rock-forming moissanite (natural silicon carbide). Am. Mineral. 2003, 88, 1817-1821. [CrossRef]

34. Curien, H.; Guillemin, C.; Orcel, J.; Steinberg, M. La hibonite, nouvelle espece minerale. Comptes Rendus Acad. Sci. 1956, 242, 2845-2847. (In French)

35. Rakotondrazafy, M.A.; Moine, B.; Cuney, M. Mode of formation of hibonite $\left(\mathrm{CaAl}_{12} \mathrm{O}_{19}\right)$ within the U-Th skarns from the granulites of S-E Madagascar. Contrib. Mineral. Petrol. 1996, 123, 190-201. [CrossRef]

36. Ulianov, A.; Kalt, A. Mg-Al Sapphirine-and Ca-Al Hibonite-bearing Granulite Xenoliths from the Chyulu Hills Volcanic Field, Kenya. J. Petrol. 2006, 47, 901-927. [CrossRef]

37. Konovalenko, S.I.; Ananyev, S.A.; Garmayeva, S.S. Rare and new minerals of the Tashelga-Maizaskaya zone of Gornaya Shoriya, their peculiarities and nature. J. Sib. Fed. Univ. Eng. Technol. 2012, 5, 301-310.

38. Wild, M.; Milisenda, C.C. Hibonit aus Myanmar (Burma). Z. Dt. Gemmol. Ges. 2013, 62, 25-30.

39. Hazen, R.M.; Grew, E.S.; Downs, R.T.; Golden, J.; Hystad, G. Mineral ecology: Chance and necessity in the mineral diversity of terrestrial planets. Can. Mineral. 2015, 53, 295-324. [CrossRef]

40. Sruoga, P.; Ibanes, O.; Japas, M.S.; Urbina, N.E. El Morro caldera ( $\left.33^{\circ} 10^{\prime} \mathrm{S}, 66^{\circ} 24^{\prime} \mathrm{W}\right)$, San Luis, Argentina: An exceptional case of fossil pre-collapse updoming. J. Volcanol. Geotherm. Res. 2017, 337, 81-97. [CrossRef] 